\title{
Emphasis of Yoga in the Management of Diabetes
}

\author{
Senthil Raj Thangasami ${ }^{1 *}$, Arati Lal Chandani ${ }^{2}$ and Thangasami $\mathbf{S}^{3}$
}

${ }^{1}$ Department of Medicine, Sree Balaji Medical College, Chennai, India

${ }^{2}$ Department of Medicine, Gsvm Medical College, Kanpur, India

${ }^{3}$ Department of General Medicine, Sree Sathya Sai Medical College and Research Institute, Chennai, India

\begin{abstract}
Objectives: For years, exercise has been considered a cornerstone of diabetes management, along with diet and medication. Growing evidence supports the beneficial effects of yoga in physical and mental health through down regulation of the hypothalamic-pituitary-adrenal (HPA) axis and the sympathetic nervous system (SNS). The purpose of this article is to provide a scholarly review of the literature of research studies comparing the effects of yoga and exercise in diabetes patients.

Methods: This review focuses on published research articles indexed in the PubMed, MEDLINE, Google Scholar, Science Direct and Scopus. Search criteria included research articles written in English with the key words "yoga", "diabetes mellitus (DM)", "Type 1 DM", "Type 2 DM", "Exercise". Only clinical or human studies published in English language were included. Exclusion criteria included articles that were not written in English.

Conclusion: Exercise can improve glucose uptake by improving insulin sensitivity and reducing body adiposity in both patients of type 1 and type $2 \mathrm{DM}$. Yoga is an ancient discipline designed to bring balance and health to the physical, mental, emotional, and spiritual dimensions of the individual. Yoga may be an attractive alternate to traditional aerobic exercises and strength training program, as it requires only a little space and needs no equipment and literally devoid of side effects, mainly focusing on relaxation of mind and body. It provides a less strenuous and more pleasurable exercise experience to an individual. Yoga can help the person feel better, both improving the physical fitness and elevating the mood. Numerous studies have shown positive benefits of yoga in the management of diabetes with good impact on glycemic control, lipid profile and cardiovascular status. Further it can alleviate stress. Yoga can be considered as a good alternate for exercise therapy.
\end{abstract}

Keywords: Diabetes; Exercise therapy; Yoga benefit

\section{Introduction}

Diabetes mellitus (DM) is a chronic progressive metabolic disorder characterized by hyperglycemia mainly due to absolute (Type 1 $\mathrm{DM}$ ) or relative (Type $2 \mathrm{DM}$ ) deficiency of insulin hormone [1]. The problem of diabetes has grown enormously in the last two decades. In 2014 , around 387 million people had diabetes with a prevalence of $8.3 \%$; by 2035 this will rise to 592 million. North America and the Caribbean is the region with the highest prevalence of $11 \%$ having 37 million people with diabetes followed by the Middle East and North Africa with a prevalence of $9.2 \%$ having 35 million people with diabetes. Western Pacific is the region with higher number of people living with diabetes (138 million); however its prevalence is $8.6 \%$, close to the prevalence of the World. The International Diabetes Federation (IDF) currently states that the top 5 countries with highest amount of diabetic patients are china, India, United States, Russia and Brazil. The number of people with type 2 diabetes is increasing in every country.77\% of people with diabetes live in low- and middle-income countries. 179 million people with diabetes are undiagnosed. Diabetes caused 4.9 million deaths in 2014 [2]. Primary prevention of diabetes by life style modification is a feasible solution to arrest the rising epidemic of the disease. Government and non-government organizations should create awareness about the disease among public and also teach them way to self-care and benefits of lifestyle modification.

\section{Factors responsible for rising incidence}

Diabetes may result due to a lot of genetic-environmental interactions. The growing incidence of diabetes is mainly attributable due to the increasing rates of urbanization, migration from rural to urban areas and adoption of sedentary life style and unhealthy diet habits $[3,4]$.
Obesity: Obesity frequently accompanies type 2 diabetes and many studies have shown it to be a powerful predictor of development of type 2 diabetes [5,6]. Obesity has increased rapidly in many populations in recent years because of an interaction between genetic and environmental factors such as metabolic characteristics, physical inactivity and high calorie composition of the diet [5]. This increase in obesity has been accompanied by an increasing prevalence of type 2 diabetes. Those with higher Body Mass Index (BMI) have much higher incidence rates of type 2 diabetes at earlier ages than those with lower BMI among whom the incidence rise in the older age groups. A child gaining BMI faster than their peers is shown to be at increased risk of DM or metabolic syndrome later in life [7].

Obesity, especially abdominal obesity is considered as a strong risk factor for Type $2 \mathrm{DM}$ both in adults and children. Increased visceral fat is independently related to both increased insulin resistance and decreased insulin secretion. Amount of visceral fat in obese adolescents is directly correlated with basal and glucose stimulated hyperinsulinemia and inversely relate with insulin sensitivity. Several studies indicate that waist circumference or waist-to-hip ratio may be a

*Corresponding author: Senthil Raj, MD, PIt No 26, 27, Concept Homes, Bharathidasan Street, Ags Colony, Ramnagar (North), Madipakkam, Chennai-600091, India, Tel: 9943367902; E-mail: sencon85@yahoo.co.in

Received September 17, 2015; Accepted October 06, 2015; Published October 09, 2015

Citation: Thangasami SR, Chandani AL, Thangasami S (2015) Emphasis of Yoga in the Management of Diabetes. J Diabetes Metab 6: 613. doi:10.4172/21556156.1000613

Copyright: () 2015 Thangasami SR, et al. This is an open-access article distributed under the terms of the Creative Commons Attribution License, which permits unrestricted use, distribution, and reproduction in any medium, provided the original author and source are credited. 
better indicator of the risk of developing diabetes than BMI [8,9]. Even though $\mathrm{BMI}$ is important in predicting the risk, distribution of fat plays a major role in assessing the risk of type $2 \mathrm{DM}$ in patients.

Lack of physical activity: During the last few decades, most of the working population had changed their lifestyle from active working occupations like agriculture to a less demanding works like office jobs. $\mathrm{TV}$, video games too makes the children refrain from regular physical activity. It was observed that the prevalence of diabetes was almost 3 times higher in individuals with sedentary life style compared to those having heavy physical activity (23.2\% vs. $8.1 \%)$ [10]. It was also noted that prevalence of metabolic syndrome and hypertension were also higher among people with light physical activity. Individuals with light grade physical activity had 2.4 times higher chance of developing coronary artery disease compared to heavy physical activity group [11].

Diet: The amount and quality of dietary fat modifies the glucose tolerance and insulin sensitivity $[12,13]$. A high fat content in the diet may result in worsening of glucose tolerance by several mechanisms including decreased binding of insulin to its receptors, impaired glucose transport, and decreased glycogen synthase and accumulation of triglycerides in skeletal muscles [14]. The fatty acid composition of the diet affects the tissue phospholipid composition and also insulin action by altering membrane fluidity and insulin signaling.

Stress: Stress is defined as a 'stimulus event of sufficient severity to produce disequilibrium in the homeostasis of physiological systems' resulting from a variety of stressors. The neuroendocrine changes accompanying stress can translate the signals into pathophysiological alterations [15]. The hypothalamic-pituitary-adrenal (HPA) axis and sympathetic nervous system (SNS) are triggered as a response to a stressor leading to a cascade of physiologic, behavioral, and psychological effects, primarily as a result of the release of cortisol and catechol amines (epinephrine and norepinephrine). Due to repeated firing of the HPA axis and SNS, the system gets de-regulated, leading to diseases such as autoimmune disorders, obesity, diabetes, substance abuse, depression, and cardiovascular disease $[16,17]$. Stress also plays a role in diabetogenesis. Changes related to stress precipitates hyperglycemia by increasing levels of hormones like glucagon, cortisol, growth hormone, catechol amines, Corticotrophin Releasing Hormone(CRH), prolactin, leptin , neuropeptide Y. Bjorntop postulated that activation of sympathetic nervous system following stress can lead to a series of hormonal changes leading to obesity and hence diabetes. Psychosocial stress may trigger the onset of visceral obesity and metabolic syndrome. HPA has been shown to be more active in pre-menopausal centrally obese women and in centrally obese men. Central android obesity and peripheral gynecoid obesity is associated with differential regulation of HPA and also targets metabolically important tissues such as liver and visceral fat. Chronic psychological stress was correlated with prevalence of type 2 diabetes mellitus and with visceral adiposity. The numbers of stressful events were positively associated with the prevalence of newly diagnosed diabetes [18].

Life style intervention: Diet, medicines (insulin /OAD/other injectable), education and exercise are the mainstay in the management of diabetes. However, exercise is the most neglected part of management. If a proper exercise program accompanies the treatment, it would lead to drastic beneficial effects.

\section{Role of exercise in DM}

Physical activity refers to a behavior, specifically a body movement that occurs from skeletal muscle contraction and results in increased energy expenditure above resting metabolic rate. Exercise, or "exercise training," is a specific type of physical activity that is performed with the intention of enhancing components of physical fitness [19]. Physical inactivity can initiate and accelerate the pathogenesis of diabetes and subsequent morbidity and mortality. Conversely, regular physical activity can retard the progression from one stage to another, and it may even reverse the process. Numerous studies have shown that moderate physical activity has decreased the risk of diabetes considerably [20].

Types of exercise training include [21] (Table 1):

1. aerobic exercise

2. endurance type exercise

3. passive exercise

4. resistance exercise

\section{Effect of aerobic exercise in type 2 DM}

Aerobic exercise is the exercise which improves oxygen consumption and increases the functioning of the cardiovascular and respiratory systems [21]. In non-diabetic persons while performing a moderate intensity exercise, the rise in the peripheral glucose uptake is matched by an equal rise in the hepatic glucose production. While a type $2 \mathrm{DM}$ patient performs a moderate exercise, the blood glucose(BG) utilization by muscles usually rise more than hepatic glucose production, and BG levels tends to decline, the risk of exerciseinduced hypoglycemia is minimal, if there is no use of exogenous insulin or insulin secretagogues [22].

While performing, intense aerobic exercise, plasma catecholamine levels rise markedly producing a surge in the glucose production. Hyperglycemia can result from such activity and persist for up to 1-2 hours, because plasma catecholamine levels and glucose production do not return to normal, immediately with cessation of the activity [23]. Aerobic exercises comprise of swimming, cycling, and treadmill,

\section{Structural changes in skeletal muscle}

$\uparrow$ fiber size

$\uparrow$ percentage of type lla fibers (Possibly type I fibers)

$\uparrow$ the capillary density and blood flow

Biochemical changes in skeletal muscle

$\uparrow$ insulin signaling kinetics (1-phosphatidyl inositol 3-kinase and GLUT4 activity)

$\uparrow$ non-insulin signaling kinetics ( 5'-AMP-activated protein kinase activity)

$\uparrow$ enzymes related to glucose metabolism [hexokinase, glycogen synthase, and key oxidative enzymes (e.g., citrate synthase, aconitase, succinate dehydrogenase)] $\uparrow$ myoglobin

Systemic influences of physical activity

$\uparrow$ oxygen uptake and functional capacity at submaximal and maximal workloads

$\uparrow$ lipoprotein lipase and other key enzymes to improve lipid control

$\downarrow$ excessive hepatic secretion of glucose and VLDL

Improvements in counter-regulatory hormone levels/activity (e.g. Cortisol, IGF-I)

Improvements in comorbid conditions (e.g., hypertension, visceral obesity, systemic inflammation, dyslipidemia)

Table 1: Potential mechanisms by which exercise enhance glucose homeostasis [21]. 
walking, rowing, running and jumping rope [24]. Moderate aerobic exercise leads to maintenance of the blood pressure in diabetic neuropathy patients [25]. Aerobic exercise improves the physiological parameters like fasting blood-glucose level, glycemic control and lipid profile. It reduces the arterial stiffness and can restore the endothelial function, and reduces the risk for developing cardiovascular complications in type $2 \mathrm{DM}$ [26-28] and is a valuable therapeutic strategy for type $2 \mathrm{DM}$. A systemic review of 25 studies with most of them being randomized trials showed that aerobic exercises are beneficial in type $2 \mathrm{DM}[21]$.

\section{Effect of resistance exercise in type $2 \mathrm{DM}$}

Resistance exercise helps to develop proper glucose control and less insulin resistance among type 2 DM. Resistance exercises are exercises that have to be performed against resistance. Example: Weight lifting. Unlike aerobic exercise, resistance exercises are relied on the Equipment. Resistance training has been reported to enhance insulin sensitivity, daily energy expenditure and quality of life [29]. Resistance training increases muscle strength, lean muscle mass, and bone mineral density, which could enhance functional status and glycemic control and assist in the prevention of sarcopenia and osteoporosis [30,31]. In the absence of contraindications, people with type 2 diabetes should be encouraged to perform resistance exercise, three times a week, targeting all major muscle groups, progressing to three sets of 8-10 repetitions at a weight that cannot be lifted more than 8-10 times.

A combination of aerobic and resistance training may be more effective for BG management than either type of exercise alone. Resistance training will lead to increase in muscle mass and contribute to BG uptake without altering the muscle's intrinsic capacity to respond to insulin, whereas aerobic exercise enhances its uptake via a greater insulin action, independent of changes in muscle mass or aerobic capacity [32].

\section{Other types of exercises in type $2 \mathrm{DM}$}

Endurance exercise involves the use of several large groups of muscles, which depends on the delivery of oxygen to the muscles by the cardiovascular system. Passive exercise needs to include another person or outside force, or produced by voluntary effort of another segment of the patient's own body [33]. There is paucity of studies on these types of exercise in treating type $2 \mathrm{DM}$.

\section{Recommendation of exercise duration in type $2 \mathrm{DM}$}

Joint ACSM/American Heart Association Guidelines recommends at least $150 \mathrm{~min} /$ week of moderate- intensity aerobic physical activity (40 -60\% of $V \mathrm{O} 2 \mathrm{max}$ or $50-70 \%$ of maximum heart rate) and/or at least $90 \mathrm{~min} /$ week of vigorous aerobic exercise $(60 \%$ of $\mathrm{VO} 2 \mathrm{max}$ or $70 \%$ of maximum heart rate). The physical activity should be distributed over at least 3 days/week and with no more than 2 consecutive days without physical activity [34]

\section{Effect of exercise in type $1 \mathrm{DM}$}

In Type $1 \mathrm{DM}$, only fewer reports have focused on the role of exercise, but more recent studies suggest that exercise improves blood glucose regulation, reduces the daily insulin dosage and decreases the risk of diabetes-associated complications in people with type $1 \mathrm{DM}^{36}$. There is clear evidence that aerobic exercises decrease the amount of required insulin to maintain glycemic control in people with type 1DM. A meta-analysis of 48 randomized control trials comparing exercise and type 1DM concluded that physical activity improved fitness, decreased insulin requirements, improved lipid levels, and vascular endothelial function in people with type 1DM [35]. In multiple studies using animal models of diabetes, aerobic exercise had no effect on the number or size of the insulin-producing beta-cells. However, diabetes caused a decrease in the insulin content per beta cell, which was reversed by aerobic exercise. The increased insulin content per beta cell translated into more insulin per islet in the exercised group along with greater insulin secretion in response to glucose. While these changes within the pancreas were significant, they were not sufficient statistically to reduce blood glucose levels, suggesting that exercise training may have a protective effect against the damage of oxidative stress on beta-cells. In an animal study, the IL-6 induced Glucogon like Peptide-1(GLP-1) release that occurred during exercise improved insulin secretion during subsequent meals. Unfortunately, there are no human clinical studies directly measuring the effect of exercise on the health and function of islets [36].

Exercise improves vascular complications in type $1 \mathrm{DM}$, by reducing dyslipidemia and also by controlling the oxidative stress induced damage. For people with severe type 1DM associated autonomic neuropathies, exercise should be undertaken with caution. Even lowintensity exercise can significantly increase heart rate variability in type 1DM with early cardiac autonomic neuropathy abnormalities [37].

\section{Benefits of yoga}

The word Yoga is derived from the Sanskrit word 'Yuj' meaning union of the body, breath and mind [38]. Yoga is an ancient discipline designed to bring balance and health to the physical, mental, emotional, and spiritual dimensions of the individual. Yoga's primary emphasis is upon gaining general well-being by the way of integration often incorporating three major components: held or sequences of physical postures, breathing exercises and meditation [39].

\section{Yoga practices}

Yoga therapy $[40,41]$ consists of graded sets of exercises, including very simple ones, so that all can practice on their own, even after the first lesson, whether or not they have done yoga before. Commencing with gentle stretching and breathing exercises, it varies up to a range of classical asanas and pranayama practices (Table 2).

The asanas have a variety of effects, including:

- relaxation, strengthening and balancing of muscles

- mobilization of joints

- improvement of posture

- action on pressure points

- improvement of breathing

- calming of nervous system

- Promotion of homoeostasis in cardiovascular, digestive, endocrine and other systems.

Asanas relax muscles through holding them in gently stretched positions. Mental relaxation techniques promote relaxation at all levels (muscles, autonomic system and mind), through body awareness, visualizations, etc.

Pranayama harmonizes and links the mind and body. Breathing is controlled by both conscious and unconscious neural pathways, bridging the mind and body. Improving the breathing pattern promotes health and can help in the management of many chronic ailments. 
Citation: Thangasami SR, Chandani AL, Thangasami S (2015) Emphasis of Yoga in the Management of Diabetes. J Diabetes Metab 6: 613. doi:10.4172/2155-6156.1000613

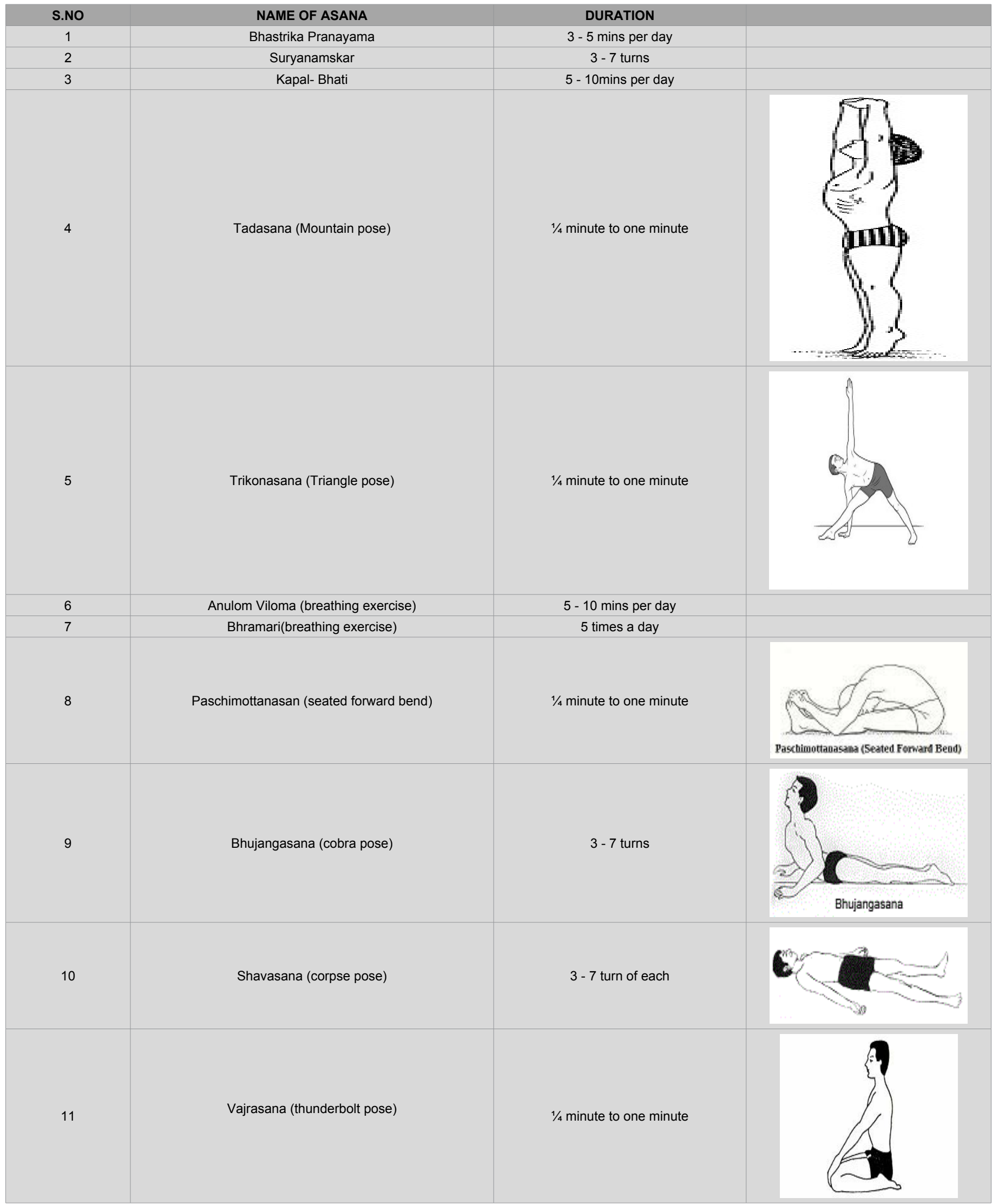


Citation: Thangasami SR, Chandani AL, Thangasami S (2015) Emphasis of Yoga in the Management of Diabetes. J Diabetes Metab 6: 613. doi:10.4172/2155-6156.1000613

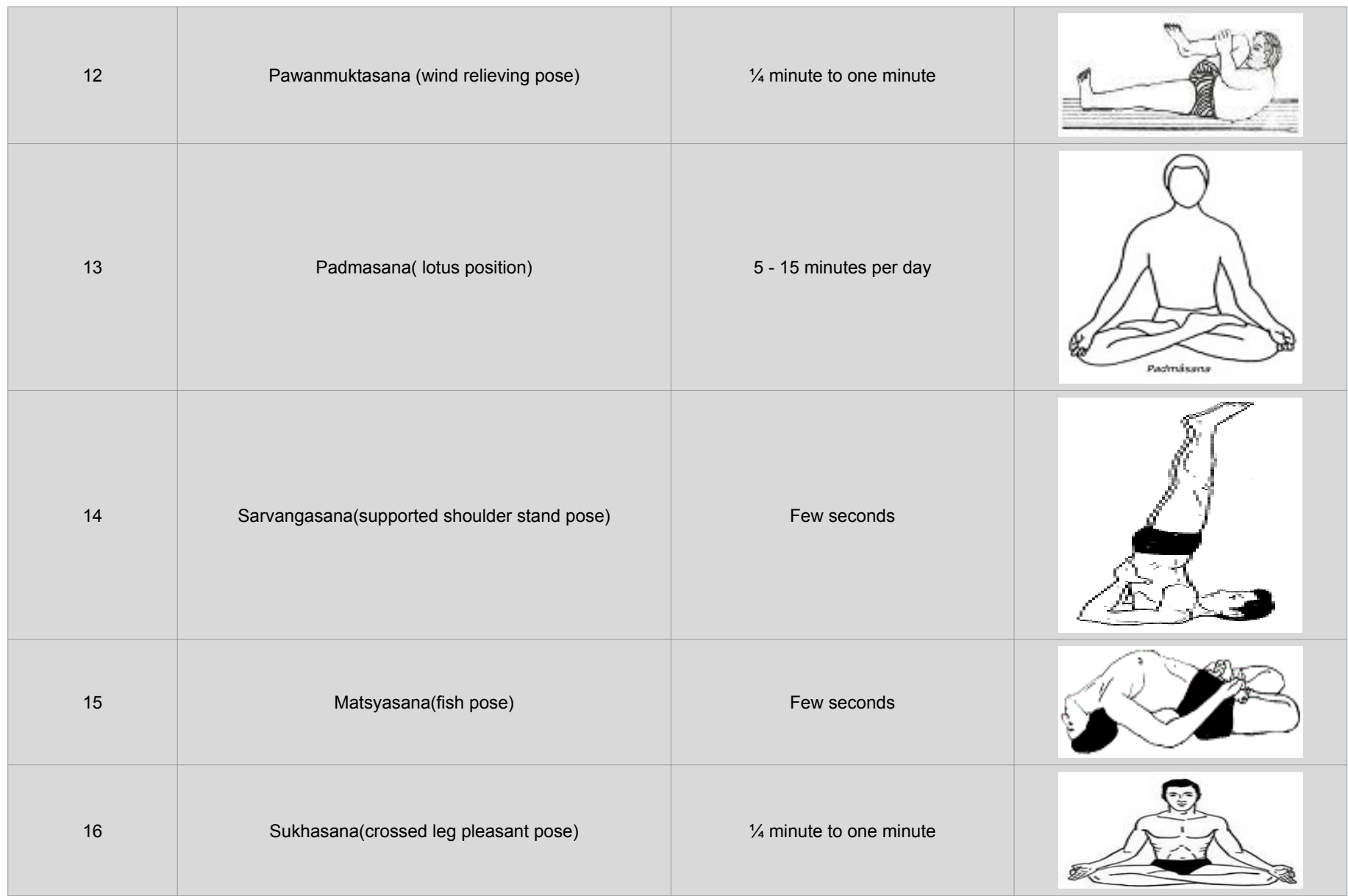

Table 2: Name and duration of various pranayama and yoga asana included in yogic exercises for type 2 diabetes on the basis of available literature [41]

Yoga is now regarded as a complementary for self-management of many stress related disorders like diabetes, Coronary Artery Disease $(\mathrm{CAD})$ etc.

\section{Beneficial Effects of Yoga}

Abdominal stretching during yoga exercise causes rejuvenation/ regeneration of cells of pancreas increasing the utilization and metabolism of glucose in peripheral tissues, liver, and adipose tissues through enzymatic process [42-44]. Improved blood supply to the muscles and muscular relaxation along with its development enhances insulin receptor expression causing increased glucose uptake and thus reducing blood sugar [45]. The improvement in the lipid levels after yoga could be due to increased hepatic lipase and lipoprotein lipase at cellular level, which affects the metabolism of lipoprotein and thus increase uptake of triglycerides by adipose tissues [46,47]. Yoga postures can lead to improvement in the sensitivity of the $\beta$-Cells of pancreas to glucose signal and also the improvement in insulin secretion [48]. Pranayama modified various inflatory and deflatory lung reflexes and interact with central neural element to bring new homeostasis in the body [49].

In an interventional research, involving 98 subjects, fasting blood sugar (FBS), serum total cholesterol, low density lipoproteins (LDL), very low density lipoproteins (VLDL), and the ratio of total cholesterol to HDL-C, and total triglycerides were significantly lower, and HDL-C significantly higher, on the last day of the course compared with the first day of the 8-days course after performing yoga [50].
In a study, 44 Type 2 DM patients were taught yoga $(\mathrm{n}=22)$ and pranayama for three continuous months, 1 hour every day in the morning, by a yoga expert. They had significant decrease in FBS, Postprandial blood sugar (PPBS), glycosylated hemoglobin (HbAlc), triglycerides and LDL of test group with $\mathrm{P}<0.001$, compared with control group $(n=22)$. The requirement of insulin in the yoga group was also significantly reduced [51].

In a study, 20 patients with type 2 diabetes mellitus were subjected to 40 days yoga routine by an expert yoga teacher. The postures performed were: Surya namaskar (sun salutation), Trikonasana (triangle pose), Tadasana (mountain pose), Padmasana (lotus pose), Bhastrika Pranayama (breathing exercise), Pashimottanasana (posterior stretch), Ardhmatsyendrasana (half spinal twist), Pawanmuktasana (joint freeing series), Bhujangasana (cobra pose), Vajrasana (thunderbolt pose), Dhanurasana (bow pose), and Shavasana (corpse pose). At the end of 40 days of performing the asanas, the study participants had a significant decrease in fasting glucose levels, waist-hip ratio and beneficial changes in insulin levels [52].

In a study involving 16 postmenopausal women with more than $36 \%$ body fat were divided into yoga group and control group. Yoga group showed improved adiponectin level, serum lipids, and metabolic syndrome risk factors in obese postmenopausal women [53].

In a retrospective study involving 15,550 adults aged 53-57 years, it was found that regular yoga practice for 4 years or more was associated with attenuated weight gain, especially among people who were 
Citation: Thangasami SR, Chandani AL, Thangasami S (2015) Emphasis of Yoga in the Management of Diabetes. J Diabetes Metab 6: 613. doi:10.4172/2155-6156.1000613

Page 6 of 11

overweight. A week of intensive yoga course reduced the BMI as well as waist and hip circumference, decreased total cholesterol, improved posture, and stability [54,55].

Numerous studies have shown yoga to have an immediate effect down regulating the response of SNS -HPA axis to stress. Studies show that yoga decreases levels of salivary cortisol, blood glucose as well as plasma renin levels, and 24-hour urine norepinephrine and epinephrine levels [56].

Most of the works related to yogic practice have been carried out only in type 2 diabetic patients. The associated risk indices have been evaluated in about 25 studies with yogic intervention ranging from 8 days to 12 months. These include decreased blood glucose levels and glycosylated hemoglobin level and also showed improvement in the glucose tolerance test (GTT). A decrease in fasting insulin level, rise in insulin receptors, increased percentage of receptor binding (even before glycemic control) suggests decreased insulin resistance and improved sensitivity $[57,58]$. There have been reports of weight loss, decrease in body mass index and waist-hip ratio, stress reduction, improvement in mood,self-efficacy and quality of life [59]. Yoga has shown improvement in nerve conduction and cognitive functions in diabetics, a feature, which may prove to be beneficial in management of diabetic complications [60,61]. In a study, Cardiac autonomic functions improved in patients with diabetes on standard treatment that followed the comprehensive yogic breathing program compared to patients who were on standard therapy alone $[62,63]$.

Yoga significantly decreases heart rate, systolic and diastolic blood pressure [64]. Studies suggest that yoga reverses the negative impact of stress on the immune system by increasing levels of immunoglobulin A as well as natural killer cells. Yoga has been found to decrease markers of inflammation such as high sensitivity C-reactive protein as well as inflammatory cytokines such as interleukin- 6 and lymphocyte-1B $[65,66]$. Leptin plays a pro-inflammatory role while adiponectin has anti-inflammatory properties. Adiponectin levels were higher among practitioners of yoga [67]. Yoga could be one such intervention that prevents the occurrence and progression of metabolic deterioration and co-morbidity (Figure 1).

\section{Yoga can benefit patients in whom exercise has a risk}

Risk of exercise in type 1 DM: Physiological, social and emotional benefits of regular exercise and physically active lifestyle are important for diabetic patients regardless of the type of diabetes [68]. Studies evaluating the efficacy of exercise in type $1 \mathrm{DM}$ were not encouraging and it may even be detrimental. If the carbohydrate intake and the insulin dosage are not adequate with the exercise of a type $1 \mathrm{DM}$ patient, it can result in metabolic disturbances [69]. Findings from exercise training studies support the concept that moderate intensity aerobic exercise increases the risk of hypoglycemia during the exercise and also several hours after the exercise.

In patients with type I diabetes with severe insulin deficiency, exercise may actually result in a paradoxical rise in both the blood glucose and ketone levels. In this situation, lack of insulin and lipolysis leads to overproduction of glucose and ketoacids that can exceed their rate of utilization [70].

There is no much study regarding the benefits of yoga in type1 DM. yoga may help in reducing the stress and induce physical well-being of patients. Stretching exercises of yoga has been found to improve the regeneration of pancreatic beta cells; it can help in type $1 \mathrm{DM}$. Further studies are necessitated to assess the benefits of yoga in type $1 \mathrm{DM}$.

Risk of exercise in type 2 DM: Regular exercise can prevent or delay the onset of type 2 diabetes in high risk populations. Because of the high incidence of occult coronary disease, patients need a cardiovascular evaluation when initiating an exercise program. High intensity exercise may result in retinal hemorrhage and transient worsening of diabetic proteinuria.

Patients suffering from complications like diabetic foot, diabetic neuropathy, denervation, loss of proprioception, all can lead to injuries in a patient while performing exercise or walking. A careful evaluation of blood flow and neurologic status of the lower extremities should be part of any pre-exercise assessment. Careful attention needs to be paid to the selection of proper footwear. Patients with severe disease may need to limit activities, such as jogging to lower impact forms of exercise [71]. Finally, it should be noted that autonomic dysfunction may place some patients at risk for developing post-exercise orthostatic hypotension, particularly during the early phase of an exercise program when autonomic dysfunction is not apparent at rest.

Micro vascular complications of diabetes could be aggravated

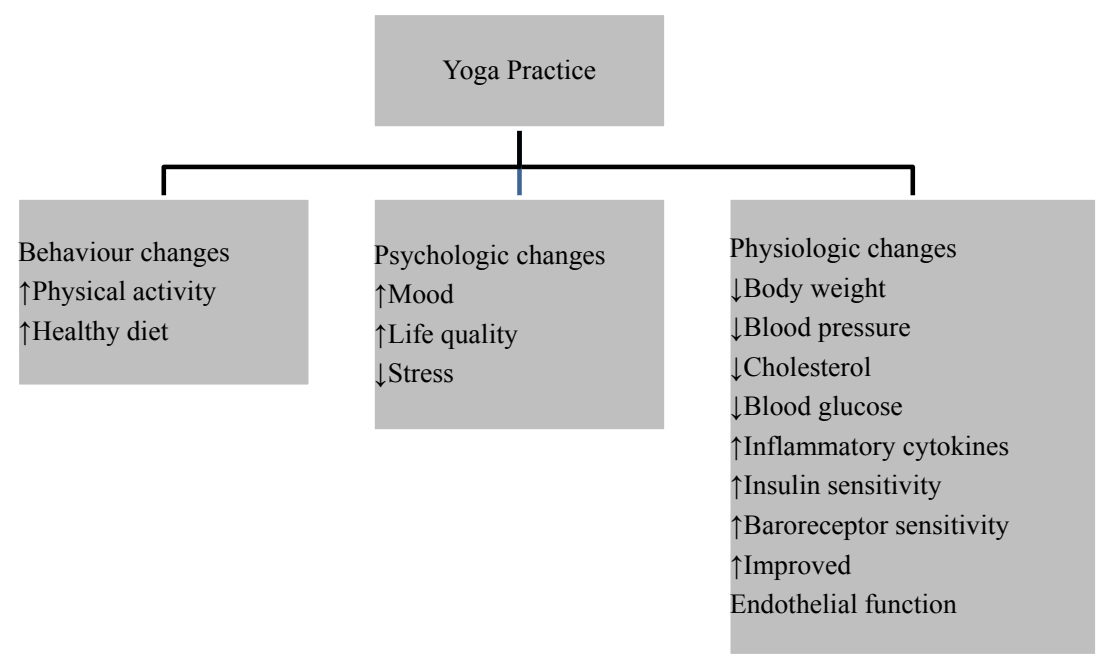

Figure 1: Effects of yoga practice. 
Citation: Thangasami SR, Chandani AL, Thangasami S (2015) Emphasis of Yoga in the Management of Diabetes. J Diabetes Metab 6: 613. doi:10.4172/2155-6156.1000613

Page 7 of 11

in some circumstances. Evidence suggests that moderately intense exercise does not induce retinopathy and may even have a protective effect [72]. However, in the presence of established proliferative disease; certain types of exercise may predispose the patient to retinal hemorrhage [73]. There is concern about the potential effects of exercise on the progression of diabetic nephropathy. Many patients with no proteinuria at rest will develop protein in their urine for as long as 12-24 hours following a single intensive bout of exercise [74]. The degree of proteinuria is roughly proportional to the rise in systolic blood pressure that occurs during the activity.

Exercise related hypoglycemia is rare in patients with type 2 diabetes, but may occur in those taking insulin or some of the more potent sulfonylureas. Exercise of the muscles directly underlying an insulin injection leads to a rapid absorption of insulin which in turn can contribute to hypoglycemia. This occurs primarily with short acting insulin and only when the exercise follows the insulin injection within a short period of time. It is easily avoided by selecting injection sites away from the area of exercising muscle. In normal circumstances, exercise results in an acute suppression of pancreatic insulin release and a decrease of serum insulin levels. In the presence of an exogenous insulin depot the normal suppression in insulin levels does not occur, resulting in a relative hyperinsulinemia [75]. In addition, some patients with long standing diabetes may develop deficiencies in glucagon and epinephrine release that could also limit their ability to maintain a normal glucose level during activity.
In a review of comparison studies [56] (Table 3), comparing the effects of yoga and exercise seem to indicate that, in both healthy and diseased populations, yoga may be as effective as/or better than exercise in improving a variety of health-related outcome measures. In this study, yoga showed a better outcome than exercise in all these parameters like HRV, kidney function, menopausal symptoms, psychiatric symptoms, pain, sleep disturbances, stress and lipid profile. Improvement in glycemic status was similar in both exercise and yoga [76]. Main difference between exercise and yoga comes mainly by the influence on the HPA axis. Intense exercise leads to proportional increases in cortisol. The critical level of intensity that leads to release of cortisol is approximately $60 \% \mathrm{VO} 2 \mathrm{max}$, with the greater the exercise intensity, the greater the cortisol release [77-80]. Perhaps this explains why yoga, involving slow and often nonstrenuous activities, positively affects the HPA axis response to stress

\section{Implications to future research}

Yoga based therapy has a good scientific background to be applied as an effective intervention in management of both type $1 \mathrm{DM}$ and type $2 \mathrm{DM}$. However, literature is inadequate in classifying the specific asanas which could benefit in diabetes and also the duration of treatment needed. Further, health administrators should plan about how yoga could effectively be taught as a life style intervention programme among public. More randomized trials in future are needed to compare the benefits of yoga and exercise.

\begin{tabular}{|c|c|c|c|c|c|c|c|}
\hline S.no & Author & Design & Population (N) & Intervention & Duration & Outcomes Measured & Results \\
\hline 1 & $\begin{array}{l}\text { Malhotra V_ } \\
{[60]}\end{array}$ & $\begin{array}{l}\text { Pre- post } \\
\text { design }\end{array}$ & 20 type 2 DM patients & $\begin{array}{l}\text { Yoga were performed } \\
\text { every day along with } \\
\text { medicines in the } \\
\text { study group while the } \\
\text { control group only with } \\
\text { medicines and light } \\
\text { excercises. }\end{array}$ & 40 days & $\begin{array}{l}\text { The basal blood glucose, } \\
\text { nerve conduction velocity } \\
\text { of the median nerve was } \\
\text { measured and repeated } \\
\text { after } 40 \text { days of Yogic } \\
\text { regime }\end{array}$ & $\begin{array}{l}\text { Control group nerve } \\
\text { function parameters } \\
\text { deteriorated over } \\
\text { the period of study, } \\
\text { indicating that diabetes } \\
\text { is a slowly progressive } \\
\text { disease involving the } \\
\text { nerves. Yoga asanas } \\
\text { have a beneficial effect } \\
\text { on glycaemic control and } \\
\text { improve nerve function in } \\
\text { mild to moderate Type } 2 \\
\text { diabetes with sub-clinical } \\
\text { neuropathy. }\end{array}$ \\
\hline 2 & $\begin{array}{l}\text { Manjunatha } \\
\text { et al. [48] }\end{array}$ & $\begin{array}{l}\text { Pre-post } \\
\text { design }\end{array}$ & 20 healthy young volunteers & $\begin{array}{l}\text { Each volunteer } \\
\text { performed four sets of } \\
\text { asanas in random order } \\
\text { for } 5 \text { consecutive days } \\
\text { each with a 2-day gap } \\
\text { between consecutive sets } \\
\text { of asanas. The four sets } \\
\text { of asanas were : } \\
\text { Dhanurasana\& } \\
\text { matsyendrasana, } \\
\text { halasana \& vajrasana } \\
\text { naukasana \& } \\
\text { bhujangasana, } \\
\text { setubandhasana\& } \\
\text { pavanamuktasana }\end{array}$ & 4-week & $\begin{array}{l}\text { Blood samples were } \\
\text { collected on days } 4 \text { and } 5 \\
\text { of each set of asanas for } \\
\text { measurement of glucose } \\
\text { and insulin levels before the } \\
\text { asanas, within } 10 \text { min after } \\
\text { performing the asanas, and } \\
30 \text { min after ingestion of } 75 \\
\text { g glucose, which in turn was } \\
\text { ingested immediately after } \\
\text { the second blood sample. A } \\
\text { standard } 75 \text { g oral glucose } \\
\text { tolerance test (OGTT) was } \\
\text { also done before and after } \\
\text { the study. On the days of } \\
\text { the pre-study or post-study } \\
\text { OGTT, no asanas were } \\
\text { done }\end{array}$ & $\begin{array}{l}\text { Performance of } \\
\text { asanas led to increased } \\
\text { sensitivity of the B } \\
\text { cells of pancreas to the } \\
\text { glucose signal. The } \\
\text { increased sensitivity } \\
\text { seems to be a sustained } \\
\text { change resulting from a } \\
\text { progressive long-term } \\
\text { effect of asanas. }\end{array}$ \\
\hline 3 & $\begin{array}{l}\text { Malhotra V_ } \\
\text { [52] }\end{array}$ & $\begin{array}{l}\text { Pre- post } \\
\text { design }\end{array}$ & 20 NIDDM patients & $\begin{array}{l}13 \text { specific Yogaasanas } \\
\text { were taught in the study } \\
\text { group and the study } \\
\text { parameters assessed } \\
\text { before and after study } \\
\text { period. }\end{array}$ & 40 days & $\begin{array}{l}\text { Serum insulin, plasma } \\
\text { fasting and one hour } \\
\text { postprandial blood glucose } \\
\text { levels and anthropometric } \\
\text { parameters were measured } \\
\text { before and after yoga } \\
\text { asanas }\end{array}$ & $\begin{array}{l}\text { At the end of } 40 \text { days of } \\
\text { performing the asanas, } \\
\text { the study participants } \\
\text { had a significant } \\
\text { decrease in fasting } \\
\text { glucose levels, waist- } \\
\text { hip ratio and beneficial } \\
\text { changes in insulin levels } \\
\text { than the previous levels. }\end{array}$ \\
\hline
\end{tabular}


Citation: Thangasami SR, Chandani AL, Thangasami S (2015) Emphasis of Yoga in the Management of Diabetes. J Diabetes Metab 6: 613. doi:10.4172/2155-6156.1000613

\begin{tabular}{|c|c|c|c|c|c|c|c|}
\hline 4 & $\begin{array}{l}\text { Bijlani RL et } \\
\text { al. [50] }\end{array}$ & $\begin{array}{l}\text { Pre- post } \\
\text { design }\end{array}$ & $\begin{array}{l}\text { heterogeneous group } \\
\text { of } 98 \text { patients with } \\
\text { hypertension, coronary } \\
\text { artery disease, diabetes mellitus, } \\
\text { and a variety of other illnesses }\end{array}$ & $\begin{array}{l}\text { yogasanas pranayama } \\
\text { (breathing exercises), } \\
\text { relaxation techniques }\end{array}$ & 9 days & $\begin{array}{l}\text { fasting plasma glucose and } \\
\text { serum lipid profile }\end{array}$ & $\begin{array}{l}\text { Fasting plasma glucose, } \\
\text { serum total cholesterol, } \\
\text { low-density lipoprotein } \\
\text { (LDL), VLDL, the ratio } \\
\text { of total cholesterol to } \\
\text { high density lipoprotein } \\
\text { (HDL) cholesterol, and } \\
\text { total triglycerides were } \\
\text { significantly lower, } \\
\text { and HDL cholesterol } \\
\text { significantly higher, on } \\
\text { the last day of the course } \\
\text { compared to the first day } \\
\text { of the course. }\end{array}$ \\
\hline 5 & $\begin{array}{l}\text { Kristal AR_ } \\
\text { [54] }\end{array}$ & $\begin{array}{l}\text { Retrospective } \\
\text { analysis }\end{array}$ & $\begin{array}{l}15,500 \text { adults recruited for VITAL } \\
\text { cohort study }\end{array}$ & $\begin{array}{l}\text { Physical activity } \\
\text { (including yoga) during } \\
\text { the past } 10 \text { years, diet, } \\
\text { height, and weight at } \\
\text { recruitment and at ages } \\
30 \text { and } 45\end{array}$ & 10 years & $\begin{array}{l}\text { Measures were based on } \\
\text { self-reporting, and past } \\
\text { weight was retrospectively } \\
\text { ascertained. }\end{array}$ & $\begin{array}{l}\text { Regular yoga practice } \\
\text { was associated with } \\
\text { attenuated weight gain, } \\
\text { most strongly among } \\
\text { individuals who were } \\
\text { overweight. Although } \\
\text { causal inference from } \\
\text { this observational study } \\
\text { is not possible, results } \\
\text { are consistent with the } \\
\text { hypothesis that regular } \\
\text { yoga practice can benefit } \\
\text { individuals who wish to } \\
\text { maintain or lose weight }\end{array}$ \\
\hline 6 & $\begin{array}{l}\text { Chaya MS } \\
{[62]}\end{array}$ & $\begin{array}{l}\text { Comparison } \\
\text { study }\end{array}$ & 30 healthy young males & $\begin{array}{l}15 \text { healthy young male } \\
\text { patients practicing } \\
\text { yoga for long termwere } \\
\text { compared with } 15 \text { young } \\
\text { males not practicing yoga }\end{array}$ & & $\begin{array}{l}\text { insulin sensitivity } \\
\text { was measured in the } \\
\text { fasting state by the } \\
\text { hyperinsulinaemic- } \\
\text { euglycaemic clamp }\end{array}$ & $\begin{array}{l}\text { Long term yoga } \\
\text { practice (for } 1 \text { year or } \\
\text { more) is associated } \\
\text { with increased insulin } \\
\text { sensitivity and attenuates } \\
\text { the negative relationship } \\
\text { between body weight or } \\
\text { waist circumference and } \\
\text { insulin sensitivity. }\end{array}$ \\
\hline 7 & Telles S [55] & $\begin{array}{l}\text { Pre- post } \\
\text { design }\end{array}$ & $\begin{array}{l}\text { single group of } 47 \text { healthy } \\
\text { persons }\end{array}$ & $\begin{array}{l}\text { persons were assessed } \\
\text { on the first and last day of } \\
\text { a yoga and diet change } \\
\text { program }\end{array}$ & 6 days & $\begin{array}{l}\text { Body mass index } \\
\text { (BMI), waist and hip } \\
\text { circumferences, mid-arm } \\
\text { circumference, body } \\
\text { composition, hand grip } \\
\text { strength, postural stability, } \\
\text { serum lipid profile and } \\
\text { fasting serum leptin levels }\end{array}$ & $\begin{array}{l}\text { A 6-day yoga and } \\
\text { diet change program } \\
\text { decreased the BMI } \\
\text { and the fat-free mass. } \\
\text { Total cholesterol also } \\
\text { decreased due to } \\
\text { reduced HDL levels and } \\
\text { a decrease in serum } \\
\text { leptin levels }\end{array}$ \\
\hline 8 & $\begin{array}{l}\text { Kyizom T- } \\
\text { [61] }\end{array}$ & $\begin{array}{l}\text { Comparison } \\
\text { study }\end{array}$ & Sixty patients of type 2 diabetes & $\begin{array}{l}\text { control group on only } \\
\text { conventional medical } \\
\text { therapy and yoga-group } \\
\text { on conventional medical } \\
\text { therapy along with } \\
\text { pranayama and yoga- } \\
\text { asana. }\end{array}$ & 45 days & $\begin{array}{l}\text { Basal recordings of } \\
\text { P300 and blood glucose } \\
\text { were taken at the time of } \\
\text { recruitment and second } \\
\text { recordings repeated after } \\
\text { forty five days for both the } \\
\text { groups. P300 was recorded } \\
\text {. }\end{array}$ & $\begin{array}{l}\text { yoga has a beneficial } \\
\text { effect on P } 300 \text { and thus } \\
\text { can be incorporated } \\
\text { along with the } \\
\text { conventional medical } \\
\text { therapy for improving } \\
\text { cognitive brain functions } \\
\text { in diabetes. }\end{array}$ \\
\hline 9 & $\begin{array}{l}\text { Balaji PA } \\
{[59]}\end{array}$ & $\begin{array}{l}\text { Comparison } \\
\text { study }\end{array}$ & 44 type 2 DM patients & $\begin{array}{l}22 \text { patients were yoga } \\
\text { group and the control } \\
\text { group did not practice } \\
\text { yoga }\end{array}$ & 3 months & $\begin{array}{l}\text { FBS, PPBS, Hb A1c, lipid } \\
\text { profile and anthropometric } \\
\text { measurements like weight, } \\
\text { BMI, Waist-hip ratio were } \\
\text { estimated before the starting } \\
\text { and at the end of the study } \\
\text { period }\end{array}$ & $\begin{array}{l}\text { Yoga group had } \\
\text { significant decrease } \\
\text { in FBS, Postprandial } \\
\text { blood sugar (PPBS), } \\
\text { glycosylated hemoglobin } \\
\text { (HbA1c), triglycerides } \\
\text { and LDL with } P<0.001 \text {, } \\
\text { compared with control } \\
\text { group }(n=22) \text {. }\end{array}$ \\
\hline
\end{tabular}


Citation: Thangasami SR, Chandani AL, Thangasami S (2015) Emphasis of Yoga in the Management of Diabetes. J Diabetes Metab 6: 613. doi:10.4172/2155-6156.1000613

Page 9 of 11

\begin{tabular}{|c|c|c|c|c|c|c|c|}
\hline 10 & $\begin{array}{l}\text { Hegde, } \\
\text { Shreelaxmi } \\
\text { V, et al. [78] }\end{array}$ & $\begin{array}{l}\text { Controlled } \\
\text { clinical trial }\end{array}$ & $\begin{array}{l}123 \text { type } 2 \text { diabetic } \\
\text { patients aged between } 40 \text { and } \\
75 \text { years }\end{array}$ & $\begin{array}{l}\text { Patients were grouped as } \\
60 \text { for yoga and } 63 \text { for } \\
\text { control }\end{array}$ & 3 months & $\begin{array}{l}\text { Malondialdehyde } \\
\text { glutathione superoxide } \\
\text { dismutase, vitamin C } \\
\text { and vitamin E were } \\
\text { measured to } \\
\text { assess the oxidative stress } \\
\text { and antioxidant status. BMI, } \\
\text { waist circumference, waist- } \\
\text { tohip } \\
\text { ratio, blood pressure, fasting } \\
\text { plasma } \\
\text { glucose (FPG), postprandial } \\
\text { plasma glucose (PPPG), } \\
\text { and HbA1c were analyzed. }\end{array}$ & $\begin{array}{l}\text { In comparison with } \\
\text { standard care alone, } \\
\text { yoga resulted in } \\
\text { significant reduction in } \\
\text { BMl, glycemic control, } \\
\text { and malondialdehyde } \\
\text { and increase in } \\
\text { glutathione and vitamin } \\
\text { C. There } \\
\text { were no differences in } \\
\text { waist circumference, } \\
\text { waist-to-hip ratio, blood } \\
\text { pressure, vitamin E, or } \\
\text { superoxide dismutase } \\
\text { in the yoga group at } \\
\text { follow-up. }\end{array}$ \\
\hline 11 & Lee [53] & $\begin{array}{l}\text { Comparison } \\
\text { study }\end{array}$ & $\begin{array}{l}16 \text { post-menopausal } \\
\text { women }>36 \% \text { body weight }\end{array}$ & $\begin{array}{l}8 \text { subjects were test } \\
\text { group taught yoga and } \\
\text { the other } 8 \text { were control }\end{array}$ & 16 weeks & $\begin{array}{l}\text { variables of body } \\
\text { composition, visceral fat, } \\
\text { serum adiponectin, and } \\
\text { metabolic syndrome factors } \\
\text { were measured in all the } \\
\text { participants before and after } \\
\text { the } 16 \text {-week study }\end{array}$ & $\begin{array}{l}\text { yoga exercise improves } \\
\text { adiponectin level, serum } \\
\text { lipids, and metabolic } \\
\text { syndrome risk factors in } \\
\text { obese postmenopausal } \\
\text { women. }\end{array}$ \\
\hline 12 & $\begin{array}{l}\text { Nagarathna } \\
\text { R, et al. [79] }\end{array}$ & $\begin{array}{l}\text { prospective } \\
\text { two-armed } \\
\text { interventional } \\
\text { randomized } \\
\text { control study }\end{array}$ & $\begin{array}{l}277 \text { type } 2 \text { diabetics of both } \\
\text { genders aged above } 28 \text { years }\end{array}$ & $\begin{array}{l}\text { study group were } \\
\text { allocated to a yoga- } \\
\text { based life style } \\
\text { modification program or } \\
\text { exercise-based life style } \\
\text { modification program. } \\
\text { Integrated yoga special } \\
\text { technique for diabetes } \\
\text { included yogasanas, } \\
\text { pranayama, meditation } \\
\text { and lectures on yogic life } \\
\text { style. Control intervention } \\
\text { included physical } \\
\text { exercises and life style } \\
\text { education }\end{array}$ & 9 months & $\begin{array}{l}\text { Medication score, blood } \\
\text { glucose, HbA1c and lipid } \\
\text { profile were assessed at } \\
\text { baseline and after } 9 \text { months. }\end{array}$ & $\begin{array}{l}\text { Yoga based life style } \\
\text { modification program is } \\
\text { similar to exercise-based } \\
\text { life style modification in } \\
\text { reducing blood glucose, } \\
\text { HbA1c, triglycerides, } \\
\text { total cholesterol } \\
\text { and VLDL. Yoga is } \\
\text { better than exercise } \\
\text { in decreasing oral } \\
\text { hypoglycemic medication } \\
\text { requirement and LDL; } \\
\text { and increasing HDL in } \\
\text { type } 2 \text { diabetics. }\end{array}$ \\
\hline 13 & $\begin{array}{l}\text { McDermott } \\
\text { et al. [80] }\end{array}$ & $\begin{array}{l}\text { Randomized } \\
\text { control trial }\end{array}$ & $\begin{array}{l}41 \text { participants with elevated } \\
\text { fasting blood glucose } \\
\text { in Bangalore, India }\end{array}$ & $\begin{array}{l}\text { Study group were } \\
\text { randomized to either } \\
\text { yoga }(n=21) \text { or a } \\
\text { walking control }(n= \\
\text { 20). Participants were } \\
\text { asked to } \\
\text { either attend yoga } \\
\text { classes or complete } \\
\text { monitored walking 3-6 } \\
\text { days per week for eight } \\
\text { weeks }\end{array}$ & 8 weeks & $\begin{array}{l}\text { Primary outcomes included: } \\
\text { changes in } \\
\text { BMI, waist circumference, } \\
\text { fasting blood glucose, } \\
\text { postprandial blood glucose, } \\
\text { insulin, insulin resistance, } \\
\text { blood } \\
\text { pressure, and cholesterol } \\
\text { and also measures of } \\
\text { psychological well-being } \\
\text { including changes in } \\
\text { depression, } \\
\text { anxiety, positive and } \\
\text { negative affect and } \\
\text { perceived stress }\end{array}$ & $\begin{array}{l}\text { Among Indians with } \\
\text { elevated fasting blood } \\
\text { glucose, participation } \\
\text { in an 8-week yoga } \\
\text { intervention resulted } \\
\text { in greater weight loss } \\
\text { and reduction in waist } \\
\text { circumference when } \\
\text { compared to a walking } \\
\text { control. There were } \\
\text { no between group } \\
\text { differences in fasting } \\
\text { blood glucose, } \\
\text { postprandial blood } \\
\text { glucose, insulin } \\
\text { resistance or any } \\
\text { other factors related } \\
\text { to diabetes risk or } \\
\text { psychological well-being. } \\
\text { There were significant } \\
\text { reductions in systolic and } \\
\text { diastolic blood pressure, } \\
\text { total cholesterol, anxiety, } \\
\text { depression, negative } \\
\text { affect and perceived } \\
\text { stress in both the } \\
\text { yoga intervention and } \\
\text { walking control over } \\
\text { the course of the study. } \\
\text { Yoga offers a promising } \\
\text { lifestyle intervention } \\
\text { for decreasing weight- } \\
\text { related type } 2 \text { diabetes } \\
\text { risk } \\
\text { factors and potentially } \\
\text { increasing psychological } \\
\text { well-being }\end{array}$ \\
\hline
\end{tabular}


Citation: Thangasami SR, Chandani AL, Thangasami S (2015) Emphasis of Yoga in the Management of Diabetes. J Diabetes Metab 6: 613. doi:10.4172/2155-6156.1000613

Page 10 of 11

\begin{tabular}{|c|c|c|c|c|c|c|c|}
\hline 14 & $\begin{array}{l}\text { V.P. } \\
\text { Jyotsna_[63] }\end{array}$ & $\begin{array}{l}\text { Randomised } \\
\text { control trial }\end{array}$ & $\begin{array}{l}120 \text { patients of diabetes on oral } \\
\text { medication along with diet and } \\
\text { exercise }\end{array}$ & $\begin{array}{l}\text { Study groups were } \\
\text { randomized into two } \\
\text { groups: (1) Continued } \\
\text { to receive standard } \\
\text { treatment for diabetes. } \\
\text { (2) Patients administered } \\
\text { comprehensive yogic } \\
\text { breathing program and } \\
\text { monitored to regularly } \\
\text { practice yoga in addition } \\
\text { to standard treatment of } \\
\text { diabetes. }\end{array}$ & 6 months & $\begin{array}{l}\text { Glycemic control, quality of } \\
\text { life and cardiac autonomic } \\
\text { function tests (CAFT) } \\
\text { were repeated after } 6 \\
\text { months of intervention and } \\
\text { compared with those before } \\
\text { randomisation. }\end{array}$ & $\begin{array}{l}\text { sympathetic cardiac } \\
\text { autonomic functions } \\
\text { significantly improved } \\
\text { from baseline in the } \\
\text { group practicing } \\
\text { comprehensive yogic } \\
\text { breathing. }\end{array}$ \\
\hline
\end{tabular}

Table 3: Studies comparing the effects of yoga.

\section{Conclusion}

Yoga is an ancient discipline designed to bring balance and health to the physical, mental, emotional, and spiritual dimensions of the individual. A comprehensive yoga therapy program has the potential to enhance the beneficial effects of standard medical management of DM and can be used in an effective complementary or integrative therapy program. The improvement in various biochemical indices and stress reduction by practicing yoga can enable a person with a better healthy living.

\section{References}

1. Zargar AH, Wani AA, Laway BA, Masoodi SR, Wani Al, et al. (2008) Prevalence of diabetes mellitus and other abnormalities of glucose tolerance in young adults aged 20-40 years in North India (Kashmir Valley). Diabetes Res Clin Pract 82: 276-281.

2. http://www.idf.org/diabetesatlas/update-2014.

3. Ramachandran A, Ma RC, Snehalatha C (2010) Diabetes in Asia. Lancet 375: 408-418.

4. Ramachandran A, Snehalatha C, Samith Shetty A, Nanditha A (2013) Primary prevention of Type 2 diabetes in South Asians--challenges and the way forward. Diabet Med 30: 26-34.

5. Steyn NP, Mann J, Bennett PH, Temple N, Zimmet P, et al. (2004) Diet nutrition and the prevention of type 2 diabetes. Public Health Nutr 7: 147-165.

6. Colditz GA, Willett WC, Stampfer MJ, Manson JE, Hennekens CH, et al. (1990) Weight as a risk factor for clinical diabetes in women. Am J Epidemiol 132: 501-513.

7. Sachdev HP, Osmond C, Fall CH, Lakshmy R, Ramji S, et al. (2009) Predicting adult metabolic syndrome from childhood body mass index: follow-up of the New Delhi birth cohort. Arch Dis Child 94: 768-774.

8. Chan JM, Rimm EB, Colditz GA, Stampfer MJ, Willett WC (1994) Obesity, fat distribution, and weight gain as risk factors for clinical diabetes in men. Diabetes Care 17: 961-969.

9. Boyko EJ, Fujimoto WY, Leonetti DL, Newell-Morris L (2000) Visceral adiposity and risk of type 2 diabetes: a prospective study among Japanese Americans. Diabetes Care 23: 465-471.

10. Mohan V, Shanthirani CS, Deepa R (2003) Glucose intolerance (diabetes and IGT) in a selected South Indian population with special reference to family history, obesity and lifestyle factors-the Chennai Urban Population Study (CUPS 14). J Assoc Physicians India 51: 771-7.

11. Mohan V, Gokulakrishnan K, Deepa R, Shanthirani CS, Datta M (2005) Association of physical inactivity with components of metabolic syndrome and coronary artery disease--the Chennai Urban Population Study (CUPS no. 15). Diabet Med 22: 1206-1211.

12. Storlien LH, Baur LA, Kriketos AD, Pan DA, Cooney GJ, et al. (1996) Dietary fats and insulin action. Diabetologia 39: 621-631.

13. Lichtenstein AH, Schwab US (2000) Relationship of dietary fat to glucose metabolism. Atherosclerosis 150: 227-243.

14. Pan DA, Lillioja S, Kriketos AD, Milner MR, Baur LA, et al. (1997) Skeletal muscle triglyceride levels are inversely related to insulin action. Diabetes 46 : 983-988.
15. Sridhar GR, Madhu K (2002) Psychosocial and cultural issues in diabetes mellitus. Curr Sci 83: 1556-64.

16. Sterling P (2004) Principles of allostasis: Optimal design, predictive regulation, pathophysiology, and rational therapeutics. In:Schulkin J, ed. Allostasis, Homeostasis, and the Costs of Physiological Adaptation. Cambridge: Cambridge University Press, 17-64.

17. McEwen BS (2000) Allostasis and allostatic load: implications for neuropsychopharmacology. Neuropsychopharmacology 22: 108-124.

18. Sridhar GR, Madhu K (2002) Psychosocial aspects of diabetes. In Ahuja MMS, Tripathy BB, Moses SGP et al. (eds). RSSDI Textbook of Diabetes. Research Society for the Study of Diabetes in India, Hyderabad, 737-755.

19. US Department of Health and Human Services (1996) Physical Activity and Health: A Report of the Surgeon General. Atlanta, GA: US Department of Health and Human Services, Centers for Disease Control and Prevention, National Center for Chronic Disease Prevention and Health Promotion.

20. LaMonte MJ, Blair SN, Church TS (2005) Physical activity and diabetes prevention. J Appl Physiol (1985) 99: 1205-1213.

21. Thent ZC, Das S, Henry LJ (2013) Role of exercise in the management of diabetes mellitus: the global scenario. PLoS One 8: e80436.

22. Minuk HL, Vranic M, Marliss EB, Hanna AK, Albisser AM, et al. (1981) Glucoregulatory and metabolic response to exercise in obese noninsulindependent diabetes. Am J Physiol 240: E458-464.

23. Marliss EB, Vranic M (2002) Intense exercise has unique effects on both insulin release and its roles in glucoregulation: implications for diabetes. Diabetes 51 Suppl 1: S271-283.

24. Ligtenberg PC, Hoekstra JB, Bol E, Zonderland ML, Erkelens DW (1997) Effects of physical training on metabolic control in elderly type 2 diabetes mellitus patients. Clin Sci (Lond) 93: 127-135.

25. Mogensen CE, Ruderman N, Devlin JT, Schneider SH, Kriska A et al. (2002) Nephropathy: early. In: Handbook of Exercise in Diabetes. (2 $2^{\text {nd }}$ edtn) American Diabetes Association, 433-449.

26. Segal KR, Edano A, Abalos A, Albu J, Blando L, et al. (1991) Effect of exercise training on insulin sensitivity and glucose metabolism in lean, obese, and diabetic men. J Appl Physiol (1985) 71: 2402-2411.

27. Yokoyama H, Emoto M, Fujiwara S, Motoyama K, Morioka T, et al. (2004) Short-term aerobic exercise improves arterial stiffness in type 2 diabetes. Diabetes Res Clin Pract 65: 85-93.

28. Poehlman ET, Dvorak RV, DeNino WF, Brochu M, Ades PA (2000) Effects of resistance training and endurance training on insulin sensitivity in nonobese, young women: a controlled randomized trial. J Clin Endocrinol Metab 85: 24632468.

29. Hunter GR, McCarthy JP, Bamman MM (2004) Effects of resistance training on older adults. Sports Med 34: 329-348.

30. Hurley BF, Roth SM (2000) Strength training in the elderly: effects on risk factors for age-related diseases. Sports Med 30: 249-268.

31. Cuff DJ, Meneilly GS, Martin A, Ignaszewski A, Tildesley HD, et al. (2003) Effective exercise modality to reduce insulin resistance in women with type 2 diabetes. Diabetes Care 26: 2977-2982.

32. Sigal RJ, Kenny GP, Boulé NG, Wells GA, Prud'homme D, et al. (2007) Effects of aerobic training, resistance training, or both on glycemic control in type 2 diabetes: a randomized trial. Ann Intern Med 147: 357-369. 
Citation: Thangasami SR, Chandani AL, Thangasami S (2015) Emphasis of Yoga in the Management of Diabetes. J Diabetes Metab 6: 613. doi:10.4172/2155-6156.1000613

Page 11 of 11

33. Boulé NG, Kenny GP, Haddad E, Wells GA, Sigal RJ (2003) Meta-analysis of the effect of structured exercise training on cardiorespiratory fitness in Type 2 diabetes mellitus. Diabetologia 46: 1071-1081.

34. Colberg, Sheri R (2010) Exercise and type 2 diabetes the American College of Sports Medicine and the American Diabetes Association: joint position statement executive summary. Diabetes care 33.12 (2010): 2692-2696.

35. Chimen M, Kennedy A, Nirantharakumar K, Pang TT, Andrews R, et al. (2012) What are the health benefits of physical activity in type 1 diabetes mellitus? A literature review. Diabetologia 55: 542-551.

36. Stehno-Bittel L (2012) Organ-based response to exercise in type 1 diabetes. ISRN Endocrinol 2012: 318194

37. Howorka K, Pumprla J, Haber P, Koller-Strametz J, Mondrzyk J, Schabmann A (1997) Effects of physical training on heart rate variability in diabetic patients with various degrees of cardiovascular autonomic neuropathy. Cardiovascular Research 34: 206-214.

38. HH Sri Sri Ravi Shankar (2011) Patanjali Yog Sutras-A commentary ( $1^{\text {st }}$ edtn), India: Sri Sri Publication Trust.

39. lyengar, Bellur Krishnamachar Sundaraja (1965) Light on yoga.

40. Monro, Robin (1997) Yoga therapy. Journal of Bodywork and Movement Therapies 1: 215-218.

41. Nayak NN, Shankar K (2004) Yoga: a therapeutic approach. Phys Med Rehabil Clin N Am 15: 783-798, vi.

42. Balaji PA, Varne SR, Ali SS (2012) Physiological effects of yogic practices and transcendental meditation in health and disease. N Am J Med Sci 4: 442-448.

43. Dang KK, Sahay BK (1999) Yoga and Meditation, Medicine update. In: Singh MM, editor. The Association of Physicians of India. Vol. 9. New Delhi: APICON, The Association of Physicians of India conference 502-512.

44. Sahay BK, Murthy KJR (1988) Long term follow up studies on effect of yoga in diabetes. Diab Res Clin Pract 5: S655.

45. Chandratreya S (2012) Diabetes and Yoga.

46. Delmonte MM (1985) Biochemical indices associated with meditation practice: a literature review. Neurosci Biobehav Rev 9: 557-561.

47. Tulpule TH, Shah HM, Shah SJ, Haveliwala HK (1971) Yogic exercises in the management of ischaemic heart disease. Indian Heart J 23: 259-264.

48. Manjunatha S, Vempati RP, Ghosh D, Bijlani RL (2005) An investigation into the acute and long-term effects of selected yogic postures on fasting and postprandial glycemia and insulinemia in healthy young subjects. Indian J Physiol Pharmacol 49: 319-324.

49. Jerath RJ, Edry VA, Barnes VA, Jerath V (2006) Physiology of long pranayamic breathing: Neural respiratory elements may provide a mechanism that explains how slow breathing shifts the autonomic nervous system. Med Hypotheses 67: 566-71.

50. Bijlani RL, Vempati RP, Yadav RK, Ray RB, Gupta V, et al. (2005) A brief but comprehensive lifestyle education program based on yoga reduces risk factors for cardiovascular disease and diabetes mellitus. J Altern Complement Med 11: 267-74.

51. Balaji PA, Varne SR, Sadat-ali S (2011) Effects of yoga - pranayama practices on metabolic parameters and anthropometry in type 2 diabetes. International Multidisciplinary Research Journal. 1: 1-4.

52. Malhotra V, Singh S, Tandon OP, Sharma SB (2005) The beneficial effect of yoga in diabetes. Nepal Med Coll J 7: 145-147.

53. Lee JA, Kim JW, Kim DY (2012) Effects of yoga exercise on serum adiponectin and metabolic syndrome factors in obese postmenopausal women. Menopause 19: $296-301$.

54. Kristal AR, Littman AJ, Benitez D, White E (2005) Yoga practice is associated with attenuated weight gain in healthy, middle-aged men and women. Altern Ther Health Med 11: 28-33.

55. Telles S, Naveen VK, Balkrishna A, Kumar S (2010) Short term health impact of a yoga and diet change program on obesity. Med Sci Monit 16: CR35-40.

56. Ross A, Thomas S (2010) The health benefits of yoga and exercise: a review of comparison studies. J Altern Complement Med 16: 3-12.

57. Mahajan AS (2014) Role of yoga in hormonal homeostasis. International Journal of Clinical and Experimental Physiology 1: 173.
58. Yang K (2007) A review of yoga programs for four leading risk factors of chronic diseases. Evid Based Complement Alternat Med 4: 487-491.

59. Balaji PA, Varne SR, Ali SS (2011) Effect of yoga pranayama practices on metabolic parameters and anthropometry in type 2 diabetes. Int Multidiscip Res J 1: 1-4.

60. Malhotra V, Singh S, Tandon OP, Madhu SV, Prasad A, et al. (2002) Effect of Yoga asanas on nerve conduction in type 2 diabetes. Indian J Physio Pharmacol 46: 298-306.

61. Kyizom T, Singh S, Singh KP, Tandon OP, Kumar R (2010) Effect of pranayama $\&$ yoga-asana on cognitive brain functions in type 2 diabetes-P3 event related evoked potential (ERP). Indian J Med Res 131: 636-640.

62. Chaya MS, Ramakrishnan G, Shastry S, Kishore RP, Nagendra H, et al. (2008) Insulin sensitivity and cardiac autonomic function in young male practitioners of yoga. Natl Med J India 21: 217-221.

63. Jyotsna VP, Ambekar S, Singla R, Joshi A, Dhawan A, et al. (2013) Cardiac autonomic function in patients with diabetes improves with practice of comprehensive yogic breathing program. Indian J Endocrinol Metab 17: 480-5.

64. McCaffrey R, Ruknui P, Hatthakit U, Kasetsomboon P (2005) The effects of yoga on hypertensive persons in Thailand. Holist Nurs Pract 19: 173-180.

65. Rao RM, Telles S, Nagendra HR (2008) Effects of yoga on natural killer cell counts in early breast cancer patients undergoing conventional treatment. Comment to: recreational music-making modulates natural killer cell activity, cytokines, and mood states in corporate employees Masatada Wachi, Masahiro Koyama, Masanori Utsuyama, Barry B. Bittman, Masanobu Kitagawa, Katsuiku Hirokawa. Med Sci Monit 13: CR57-CR70. Med Sci Mon 14: 3-4.

66. Pullen PR, Nagamia SH, Mehta PK, Thompson WR, Benardot D, et al. (2008) Effects of yoga on inflammation and exercise capacity in patients with chronic heart failure. J Card Fail 14: 407-413.

67. Kiecolt-Glaser JK, Christian LM, Andridge R, Hwang BS, Malarkey WB, et al. (2012) Adiponectin, leptin, and yoga practice. Physiol Behav 107: 809-813.

68. Lukács A, Barkai L (2015) Effect of aerobic and anaerobic exercises on glycemic control in type 1 diabetic youths. World J Diabetes 6: 534-542.

69. Berger M, Berchtold P, Cüppers HJ, Drost H, Kley HK, et al. (1977) Metabolic and hormonal effects of muscular exercise in juvenile type diabetics. Diabetologia 13: 355-365.

70. Angadi SS, Gaesser GA (2009) Pre-exercise cardiology screening guidelines for asymptomatic patients with diabetes. Clin Sports Med 28: 379-392.

71. Cavanagh PR, Ulbrecht JS (1993) Biomechanics of the foot in diabetes mellitus. In: Levin ME, O'Neal LW, Bowker JH (eds). Diabetic Foot. (5 $5^{\text {th }}$ edtn). St. Louis, MO: Mosby 199-232.

72. Cruickshanks KJ, Moss SE, Klein R, Klein BE (1992) Physical activity and proliferative retinopathy in people diagnosed with diabetes before age $30 \mathrm{yr}$. Diabetes Care 15: 1267-1272.

73. Sharuk GS, Stockman ME, Krolewski AS (1986) Patient activity and the risk of vitreous hemorrhage in eyes with proliferative diabetic retinopathy (abstract). Invest Ophathalmol 27: 246.

74. Campanacci L, Faccini L, Englaro E, Rustia R, Guarnieri GF, et al. (1981) Exercise-induced proteinuria. Contrib Nephrol 26: 31-41.

75. Frid A, Ostman J, Linde B (1990) Hypoglycemia risk during exercise after intramuscular injection of insulin in thigh in IDDM. Diabetes Care 13: 473-477.

76. Howlett TA (1987) Hormonal responses to exercise and training: a short review. Clin Endocrinol (Oxf) 26: 723-742.

77. Davies CT, Few JD (1973) Effects of exercise on adrenocortical function. J Appl Physiol 35: 887-891.

78. Hegde, Shreelaxmi V (2011) Effect of 3-Month Yoga on Oxidative Stress in Type 2 Diabetes With or Without Complications A controlled clinical trial. Diabetes care 34: 2208-2210.

79. Nagarathna R (2012) Efficacy of yoga based life style modification program on medication score and lipid profile in type 2 diabetes-a randomized control study. International Journal of Diabetes in Developing Countries 32: 122-130.

80. McDermott KA, Rao MR, Nagarathna R, Murphy EJ, Burke A, et al. (2014) A yoga intervention for type 2 diabetes risk reduction: a pilot randomized controlled trial. BMC Complement Altern Med 14: 212. 